\title{
CORRIGENDUM
}

\section{Salinisporamycin, a novel metabolite from Salinispora arenicora}

Satoru Matsuda, Kyoko Adachi, Yoshihide Matsuo, Manabu Nukina and Yoshikazu Shizuri

The Journal of Antibiotics (2009) 62, 537; doi:10.1038/ja.2009.91

Correction to: The Journal of Antibiotics (2009) 62, 519-526; doi:10.1038/ja.2009.75

The authors of the above article noted an error in the publication of this paper (AOP and in this issue) in the spelling of the bacterium Salinispora arenicora in the title and throughout the text. The correct spelling of this bacterium is Salinispora arenicola. 